\title{
De verantwoordelijkheid van de sociale wetenschapper tijdens de COVID-19-pandemie
}

\author{
Koen Van Aeken
}

\section{Een themanummer over corona en recht?}

In zijn doortocht langs de openbare markten, de ic-afdelingen van ziekenhuizen, de traditionele en digitale nieuwsmedia, de labo's van virologen en microbiologen, de databanken van epidemiologen, de thuiswerkplekken van sociale wetenschappers, de politieke partijen, de politierechtbanken, de Nederlandse kroegen en Belgische cafés, de woonzorgcentra en verzorgingshuizen, de aandelenbeurzen en zoveel andere maatschappelijke instituties laat het nieuwe coronavirus ook Recht der Werkelijkheid niet ongemoeid. Mea culpa aan de lezers die hoopten op een coronavrij themanummer. Ik vrees, midden oktober, dat ik deze lezers nog verder moet teleurstellen. Laat varen alle hoop, gij die de kringen van sociaalwetenschappelijke onderzoekers van het recht binnentreedt met de wens dat het virus hier niet domineert.

Een voorzichtige extrapolatie van de wetenschappelijke reactie op de pandemie over de periode 1 maart tot 15 oktober brengt namelijk nieuwe ankerpunten in kaart voor het sociaalwetenschappelijk onderzoek van het recht voor de komende jaren. Buiten kijf staat dat wetgeving, regulering en handhaving bedoeld om de verspreiding en impact van het coronavirus onder controle te houden, en in het kielzog daarvan de juridische bescherming en gerechtelijke sanctionering, populaire thema's zullen worden. Maar is zoveel aandacht wel gewenst? Kannibaliseert het coronaonderzoek immers niet ander essentieel onderzoek? Worden in een competitieve onderzoeksmarkt thema's als discriminatie in ordehandhaving, digitale reproductie van ongelijkheid in het recht en de klimaatverandering, niet beroofd van broodnodige budgetten en denkkracht?

Dergelijke vragen zijn zeker legitiem. Of zoveel aandacht voor corona wenselijk is, is echter een normatief vraagstuk. Een empirische discipline als de rechtssociologie of -psychologie weet hier geen raad mee. Een vraag die wel beantwoord kan worden, is waarom zoveel onderzoeksgeld en academische aandacht naar corona gaat. Aan de coronacrisis wordt namelijk een sense of urgency toegedicht die andere onderwerpen momenteel ontberen. Het gevoel van hoogdringendheid is latent en manifest aanwezig. Op de vaststelling dat het virus al meer dan een miljoen doden heeft geëist, reageert Tobias Arnoldussen bijvoorbeeld als volgt: 'Veel tijd om bij deze ramp stil te staan is er echter niet.' Die sense of urgency is zo krachtig, dat zij ook op flankerende thema's afstraalt. Zo stellen de themanummerauteurs Frans van Dijk en Eddy Bauw dat in de coronacrisis 'urgent een discussie nodig is over hoe fundamentele processuele rechten op andere (digitale) 
wijze dan fysiek (of een combinatie van beide) betekenisvol kunnen worden ingevuld'. De beperking van fysiek contact en de keuze voor online zittingen dreigen namelijk te resulteren in onvoldoende bescherming van de rechten van verdachten, bijvoorbeeld in de zin van veronachtzaming van het beginsel van hoor en wederhoor, en schending van artikel 6 EVRM, doordat aanwezigheid in persoon en contact met de advocaat ter zitting onmogelijk is. Maar het volume van het aantal rechtszaken blijft beperkt, in weerwil van de plausibele veronderstelling dat de ingrijpende maatregelen van de overheid bedrijven en burgers zou aanzetten om het recht te mobiliseren. Ook uit de slachtofferhoek was er ook veel kritiek, omdat zij niet aanwezig mochten zijn op de zittingen (en als het wel mocht, zonder ondersteuning.). Aanvullend past ook de waarschuwing dat online rechtspraak bestaande ongelijkheden kan reproduceren, net zoals bijvoorbeeld online onderwijs dat doet. Overigens manifesteert de problematiek van ongelijkheid zich niet enkel in de scheve verdeling van de negatieve gevolgen van COVID-19 en de overheidsmaatregelen om de verspreiding van de ziekte te beteugelen, maar ook aan de basis, dat wil zeggen op het niveau van de verspreiding van het nieuwe coronavirus en COVID-19 zelf. De meer kwetsbare sociaaleconomische groepen beschikken op talrijke dimensies over minder mogelijkheden om zich tegen infectie met het virus te beschermen. En eenmaal geïnfecteerd ondermijnen de minder gezonde leefwijze en de slechtere toegang tot de zorg de kans op herstel.

Dat het virus op ongelijke wijze toeslaat, betekent echter niet dat sommige maatschappelijke groepen onaantastbaar zijn. Iedereen kan slachtoffer worden (zij het met een verschillende probabiliteit). Dat idee wakkert een grensoverschrijdende existentiële onrust aan die het gevoel voedt dat dringend actie ondernomen moet worden om de pandemie in te dijken. Om het even concreet te maken: in een videocall tussen broers en zus in Antwerpen, Toulouse, Londen en San Diego eind maart 2020 werd confronterend duidelijk hoe gelijkaardig en indringend de maatregelen waren die diverse overheden oplegden om de verspreiding van het virus tegen te gaan. Enkel al het idee dat de bevolking een lockdown en social distancing opgelegd zouden worden, was vóór die tijd gereserveerd voor dystopische ontspanning à la Dark Mirror. Maar bovenal ongelofelijk was het besef van de mondiale schaal van de crisis. Wegvluchten naar een ander continent op zoek naar bescherming tegen een of ander soort kwaad, zoals miljoenen migranten in de geschiedenis hebben voorgedaan, is voor het eerst in de geschiedenis geen realistische optie. Enkel een kleine elite kan het zich veroorloven om naar een buitenhuis of een onbewoond eiland te vluchten. Voor de andere stervelingen zit er niets anders op dan de basisregels zo goed mogelijk opvolgen: afstand houden, handen wassen, een mondmasker dragen... Maar deze normen naleven valt niet iedereen in de samenleving even makkelijk. Hardhorigen op leeftijd, bijvoorbeeld, hebben het moeilijker met het naleven van physical distancing, omdat zij gewoontegetrouw hun oor dichter bij de mond van de gesprekspartner brengen. Als die spreker dan (onbewust) besmettelijk is en het mondneuskapje niet correct draagt, is infectie bijna onvermijdelijk. Zes maanden na die videocall moest dan ook een nieuwe Zoom-meeting ingepland worden om het nieuws te delen dat de pater familias met spoed opgenomen werd in het ziekenhuis met acute COVID-19- 
symptomen. Een week later werd hij mechanisch beademd en nog eens twee weken later is de goede afloop van de uitputtingsslag die COVID-19 is hoogst onzeker.

Het nare resultaat is dat ik als auteur van dit redactioneel met meerdere dimensies van COVID-19 wordt geconfronteerd. Mijn professionele woordenschat wordt op persoonlijk vlak aangevuld met medisch jargon als 'acceptabele zuurstofsaturatie', 'intubatie' en 'kritisch ziek'. Vooral die laatste term is heftig, omdat die duidelijk maakt dat de veilige theoretische distantie tussen onderzoeker en studieobject is verdwenen.

Tegenover het delen van hoogstpersoonlijke ervaringen stellen wetenschappelijke journals zich doorgaans gereserveerd op. Toch neem ik het risico van verwijten van methodologisch individualisme voor lief om de sense of urgency van COVID-19 te illustreren. Niets is effectiever dan de persoonlijke ervaring om bewust te worden van de hoogdringendheid van een probleem. In Wissenschaft als Beruf. (1919) schreef Weber al dat de Erlebnis - de emotionele staat van de persoonlijke beleving ${ }^{1}$ - noodzakelijk is, wil de rationele onderzoeker iets nieuws voortbrengen. Naarmate COVID-19 dichterbij komt in het persoonlijk netwerk van relaties, zal de sense of urgency nog toenemen. In de persconferentie van vrijdag 16 oktober verbindt Alexander Decroo, de kersverse Belgische premier, de strengere maatregelen aan het overheersende gevoel dat het virus 'dichtbij gekomen is bij elk van ons. [...] Een groot verschil met maart/april is dat we allemaal mensen kennen die in quarantaine zijn, die ziek zijn, of die heel ernstig ziek zijn'. ${ }^{2}$ Dat corona dichterbij komt in heel West-Europa, wordt ook in kwantitatieve zin aangetoond door de tijdreeksen. De waarden van sleutelvariabelen zoals het aantal besmettingen of het aantal ic-opnames stijgen overigens zo snel, dat commentaar daarop meteen achterhaald is. Ook de politieke reacties, zoals een nieuwe noodtoestand in Frankrijk of de sluiting van de horeca in Nederland en België (vanaf 19 oktober), getuigen van die sense of urgency.

\section{Hold your horses!}

Mag een sense of urgency eigenlijk wel een wetenschapsagenda bepalen? Moet wetenschap juist niet boven de waan van de dag staan? Wat zullen toekomstige generaties van disciplinegenoten ervan vinden dat in dat vermaledijde jaar 2020 het jaarlijkse themanummer van Recht der Werkelijkheid gewijd werd aan hét thema van het jaar? Misschien heeft die sense of urgency te veel aandacht gekregen en worden andere motieven overschaduwd. Daarom haal ik ook enkele andere mogelijke drijfveren aan. Moet dit coronanummer misschien gezien worden als een invulling van de breed gekoesterde wens om de studie van recht en samenleving nu écht te verbinden met de 'levende samenleving' en de sociale problemen van het hier en het nu? Of is het net omgekeerd en biedt dit themanummer een expositie van de blijvende conceptuele en theoretische rijkdom van de law and

1 Weisz 2020, p. 10.

2 vrt.be/vrtnws/nl/2020/10/16/premier-de-croo-kondigt-strenge-coronamaatregelen-aan-omerge/. 
society-stroming, gecureerd rondom een idiosyncratische dagelijkse werkelijkheid? Illustreert dit nummer daarnaast misschien de veruitwendiging van de professionele plicht of ideologische overtuiging om wetenschap ten dienste van de samenleving te stellen? Of bewijst dit coronanummer enkel maar dat ook de sociaalwetenschappelijke onderzoekers van het recht niet immuun zijn voor het $\mathrm{FOMO}^{3}$-syndroom dat door de COVID-19-crisis wordt aangezwengeld: de vrees om budgetten, publicaties, maatschappelijke impact en erkenning te mislopen, nog versterkt door het 'nu of nooit'-gevoel?

Allicht is het een beetje van alles. Eerder dan ons te laten misleiden door de sensatie van hoogdringendheid moeten we ons als wetenschapper laten leiden door een sense of responsibility. Het bewust worden van de wetenschappelijke verantwoordelijkheid overstijgt motieven van individuele bias in onderwerpskeuze en -benadering of persoonlijk profijt, en richt de aandacht opnieuw op de wetenschap zelf. Deze verantwoordelijkheid heeft een aan de wetenschap externe en interne dimensie. Extern is het een drijfveer om maatschappelijke problemen te onderzoeken, die beantwoordt aan de verwachtingen die samenleving en politiek aan het beroep van wetenschapper stellen. Intern is het een concrete en altijd aanwezige richtlijn om de (empirische) onderzoekskwaliteit te bewaken en te streven naar de ontwikkeling van de eigen (deel)discipline en de theorie daarbinnen. Hieronder ga ik eerst in op de interne verantwoordelijkheid. Naast de bewaking van onder meer de juiste terminologie en definities uit die zich in de vraag wat het disciplinaire perspectief kan betekenen voor het coronaonderzoek. Vervolgens komt de externe dimensie van verantwoordelijkheid aan bod, zoals die zich in het bijzonder openbaart in de relatie tussen wetenschap en politiek. Daar zal blijken dat wetenschap en politiek op gespannen voet met elkaar kunnen staan. Ten slotte worden de vier bijdragen ingeleid en gekaderd in het raamwerk van interne en externe verantwoordelijkheid.

\section{Interne verantwoordelijkheid}

Corona verwijst naar het nieuwe coronavirus dat door de World Health Organization op 11 februari 2020 formeel SARS-CoV-2 genoemd werd. Het volgnummer 2 verwijst naar de taxonomische relatie met familielid SARS-CoV, dat in 2002 in China opdook (en net geen pandemie veroorzaakte). Die dag werd ook de formele naam bekendgemaakt voor de ziekte die dat tweede coronavirus veroorzaakte en in 2019 voor het eerst werd geregistreerd: COVID-19 of voluit Coronavirus disease 2019. De ordeningslogica van de WHO maakte dat de aard van de ziekte al duidelijk zou worden in de naam van het virus. Met Severe Acute Respiratory Syndrome Coronavirus 2 lieten de virologen van de WHO inderdaad weinig aan de verbeelding over. Dat kan verklaren waarom de termen voor virus en ziekte vanaf nu kortweg coronavirus en covid - veelvuldig door elkaar gebruikt worden. Het onderscheid is voor wetenschappelijke benaderingen natuurlijk wel belang-

3 FOMO staat voor Fear Of Missing Out: 'the fear that if you miss a party or event you will miss out on something great', Urbandictionary.com. 
rijk. Virologen en microbiologen, bijvoorbeeld, hebben geen interesse in de ziekte en bekijken het virus vanuit de plantkunde of de biologie. Epidemiologen richten hun aandacht op het voorkomen van de verspreiding van ziekten binnen en tussen populaties. Op natuurlijke wijze sluit dat blikveld beter aan op de sociaalwetenschappelijke studie van het recht. Net zoals epidemiologen zijn rechtssociologen, -economen of -psychologen maar matig geboeid door aan het virus endogene en dus onveranderlijke eigenschappen zoals de modi van transmissie, de leefbare omgevingstemperatuur, de overlevingsduur van het virus op verschillende materialen, de snelheid en afstand waarmee het virus door de lucht beweegt, de overlevingskansen van het virus als het in water terechtkomt, enzovoort.

Vanuit een sociaalwetenschappelijk perspectief gaat de meeste aandacht ruwweg naar de exogene factoren die de verspreiding kunnen manipuleren. Concreet zijn dit maatregelen om de verspreiding van het coronavirus tegen te gaan en de covidpandemie af te remmen. Zo is de microbiologische verwantschap met het SARS-virus dat in China opdook in 2002 maar van beperkte betekenis voor sociaalwetenschappelijke onderzoekers. Ze zijn daarentegen wel geïnteresseerd in de maatschappelijke aura van de bestrijdingsmaatregelen die de verschillende Aziatische landen oplegden. 'SARS outbreak contained worldwide' kondigde de World Health Organization aan op 5 juli $2003^{4}$. Omdat elke gekende overdracht van SARS-CoV van persoon tot persoon was gestopt en de SARS-epidemie niet tot een pandemie was uitgegroeid, is het verleidelijk om de toenmalige SARSmaatregelen als succesvolle beleidsinstrumenten te zien. Daarbij mogen interacties met endogene factoren echter niet uit het oog verloren worden. Besmetting met SARS-CoV mondde aanzienlijk vaker uit in een overlijden dan besmetting met SARS-Cov-2. Een fatale afloop van de ziekte, benaderd als de case fatality rate (CFR) of mortaliteitsratio, werd in 2002 of 2003 namelijk geregistreerd in ongeveer $10 \%$ van de gevallen van besmetting, en in niet minder dan $55 \%$ van de gevallen waarbij een persoon ouder dan 65 jaar besmet werd. ${ }^{5}$ De CFR van het nieuwe coronavirus ligt beduidend lager, met een globale CFR die naar een waarde lager dan $3 \%$ lijkt te regresseren, ${ }^{6}$ en een CFR die in het slechtste geval $20,2 \%$ bedroeg voor 80-plussers in het Italië van maart $2020 .^{7}$

Ondanks de methodologische zwaktes ${ }^{8}$ is de CFR een populaire indicator voor de mobiliteit van het virus - en niet enkel omwille van de bekende epidemiologische trade-off tussen mortaliteit en mobiliteit (een virus komt niet tot leven op een dode). De risicoperceptie van het SARS-virus schoot namelijk behoorlijk de hoogte in door de populaire narratief over de dodelijkheid, die na enkele maanden

4 who.int/mediacentre/releases/2003/pr56/en.

$5 \quad$ Venkatesh \& Memish 2004, p. 655; Munster e.a. 2020, p. 692.

6 ourworldindata.org/mortality-risk-covid\#the-case-fatality-rate.

7 Onder, Rezza \& Brusaferro 2020.

8 Het berekenen van de CFR (100*aantal bevestigde COVID-19-doden / aantal bevestigde COVID-19-gevallen) tijdens een pandemie is een notoire methodologische uitdaging, bijvoorbeeld omdat kritisch zieke patiënten die nog moeten overlijden niet meegeteld worden en daardoor de CFR te laag wordt ingeschat, of omdat asymptomatische dragers zelden getest worden en daardoor de CFR oneigenlijk verhoogt. Ritchie \& Roser 2020. 
van overheidsstilzwijgen en -ontkenning werd aangevuld met een wetenschappelijke, eensluidende boodschap over de gevaarlijkheid van het virus. De politieke inrichting van China liet weinig tegenspraak toe; bovendien bestonden social media nog niet in 2003, zodat er vrijwel geen bottom-up actie kon groeien om het formele narratief tegen te spreken of haar geloofwaardigheid te ondermijnen zoals in 2020 uitvoerig gebeurt. Dergelijke, aan het virus vreemde (exogene) factoren die aspecten van zijn verspreiding beïnvloeden, behoren tot de klassieke thema's van het sociaalwetenschappelijk onderzoek van het recht. Semi-autonome velden, actiegroepen, mediating roles voor internetgroeperingen, secundaire mobilisering enzovoort opereren namelijk als variabelen die een efficiënte en effectieve werking van beleid, wet- en regelgeving kunnen dwarsbomen of aanzwengelen.

Sociale wetenschappers nemen in hun onderzoek minder vaak (de genezing van) de ziekte als startpunt. Interdisciplinaire onderzoekers van het recht bestuderen liever de coronamaatregelen, die ze - al dan niet bewust - kaderen in een instrumentele beleidsopvatting. Nadenken over de totstandkoming en evalueren van de impact van maatregelen lukt blijkbaar best als vertrouwd wordt op de bekende interdisciplinaire referentiekaders over regels, overheid en samenleving. Andere theoretische raamwerken of disciplinaire benaderingen zoals de communicatieve werking van wetgeving (Willem Witteveen, Bart van Klink), de normatieve functie van de wet (Wibren van der Burg), de motivatiepsychologie (ontwikkelingspsycholoog Maarten Vansteenkiste, Universiteit Gent), sub-politiek ${ }^{9}$ (Beck) of, meer algemeen, bottom-upbenaderingen van het sociaal handelen ten aanzien van de pandemie worden beduidend minder vaak gebruikt. Dat besluit volgt uit een review van de sociaalwetenschappelijke literatuur over de overheidsmaatregelen van de afgelopen zes maanden. Ten eerste valt op hoe wordt geredeneerd vanuit latente causale schema's die het succes van een maatregel evalueren vanuit de indirecte bedoelde en onbedoelde effecten. Een tweede herkenningspunt is de valorisatie van rechtssociologische kennis over voorwaarden voor effectiviteit en handhaafbaarheid. Trefwoorden zijn hier bekendheid en begrijpbaarheid van regels, de rol van officiële handhavingsinstanties die 'tanden' aan een regel verlenen, de verhouding tussen spontane en controledimensies van naleving, en elementen van meer gesofisticeerde reflexieve regulering en compliance studies.

Verantwoordelijkheid noopt tot het erkennen van zwaktes. In weerwil van de conceptuele rijkdom aangaande informele, niet-statelijke regels blijft het 'bestuurskundig centrum' ${ }^{10}$ de belangrijkste bron van de regels die aan evaluatie worden onderworpen.

9 'Sub-politiek' is volgens hoogleraar sociale wetenschappen (KU Leuven) Rudi Laermans 'een typische Beck-uitdrukking: wervend, maar tevens een vaag containerbegrip omdat het slaat op alle soorten acties of beslissingen die raken aan het algemeen belang, zonder zich echter te voegen naar de strakke agenda's van partijen of wettelijke procedures.' De Standaard, 10 januari 2015.

10 Verderop in het artikel haal ik de Universiteit Antwerpen aan als een semi-autonoom veld waaruit de roep weerklonk om de overheidsregels te negeren. In Nederland doet het Red Team aan sub-politiek (zie ook de bijdrage van Tobias Arnoldussen). 
Evenmin vrij van contestatie is de vanzelfsprekendheid van de afbakening tot 'indirecte effecten'. Dat was al een hoofdbreker voor Griffiths, ${ }^{11}$ die stelde dat de ontwikkeling van een algemene wetgevingstheorie theoretisch onmogelijk was, omdat zo'n theorie onmogelijk elke causale relatie tussen een direct effect en het effect daarvan (het zogenaamde indirect effect) zou kunnen verklaren. Bijvoorbeeld: het sluiten van de sportgelegenheden beoogde fysiek contact tussen binnensporters te verminderen. In de gedeconstrueerde beleidslogica volgen uit de directe effecten van een maatregel de zogenoemde indirecte effecten. Het beoogde indirecte effect is uiteraard dat de epidemie afzwakt. Maar indirecte effecten kunnen ook negatief of contraproductief zijn. Doordat minder gesport wordt, kalft de fysieke en afgeleide mentale gezondheid van mensen af, waardoor het afweersysteem verzwakt en zij juist vatbaarder zouden kunnen worden voor besmetting door het coronavirus en misschien ook een ernstigere vorm van COVID-19 zouden kunnen opdoen. Nog een plausibel indirect onbedoeld en ongewenst effect is dat relationele spanningen toenemen doordat een uitlaatklep voor agressie wegvalt. Een positief onbedoeld indirect effect is dan weer dat minder spoedeisende blessures voorkomen, zodat de spoedartsen zich op de verzorging van COVID-19-zieken kunnen toeleggen.

Het uiteenzetten van de werking van een relatief eenduidige en weinig gecontesteerde coronamaatregel toont meteen aan hoezeer de ontwikkeling van beleid afhangt van aannames en schattingen. Daaraan moet dan nog de meest centrale en fragiele - hypothese toegevoegd worden, een hypothese die de kern van de beleidstheorie vormt. Dat is met name het bestaan van een causale relatie tussen direct en indirect effect. In dit geval steunt die causale relatie tussen fysiek contact tussen binnensporters terugdringen en het aantal besmettingen beperken op de theoretische premisse dat het virus zich via de lucht, via zweet of via aanraking voortplant. Dat is een aan het virus interne karakteristiek, waarvoor sociale wetenschappers beroep moeten doen op de kennis van virologen of microbiologen. Dit voorbeeld is een gemakkelijk geval, maar voor veel maatregelen geldt echter dat de theoretische aannames met betrekking tot de indirecte werking veel minder plausibel zijn. De aannames van virologen met betrekking tot de massale verspreiding van het virus tijdens cafébezoek, bijvoorbeeld, worden vurig betwist. Koppel dit aan de onzekerheid over de inschatting van allerhande onbedoelde effecten en hun interacties met de bedoelde effecten, en het wordt verbijsterend duidelijk hoezeer beleidsmakers kampen met onzekerheid en onwetendheid. En dat geldt ook voor onderzoekers die primaire analyses van secundaire data uitvoeren.

\section{Externe verantwoordelijkheid}

De externe dimensie van de verantwoordelijkheid van de wetenschapper valt grotendeels samen met de verwachtingen die de samenleving aan het beroep van wetenschapper stelt. Die verwachtingen krijgen op ideaaltypische wijze gestalte in 
de dubbele rol die wetenschappers in de literatuur en populaire media opnemen: niet enkel problemen opsporen en begrijpen, maar ook oplossingen ontwikkelen en die (laten) implementeren. Het beeld van de heldhaftige professor die tussen de drukbezochte colleges door een aankomende aardverschuiving of pandemie ontdekt, en vervolgens het vertrouwen van de politieke machtshebbers krijgt om zijn gedurfde oplossing als een echte leider door te duwen, is helaas fictie. Weber zei al dat $99 \%$ van de wetenschappers geen leiders zijn. Gelukkig maar, want om te leiden is democratische legitimiteit vereist. Idealiter bezorgen wetenschappers aan de beleidsmakers de empirische, theoretisch geïnformeerde feiten en onthouden ze zich van verdere politieke beslissingen. De vraag beantwoorden wat de samenleving behoort te doen, is immers geen wetenschappelijke taak. Toch stellen heel wat wetenschappers normatieve daden. Dat kan indirect, door methodologische keuzes te maken die het beleid sturen, maar ook direct, door een bepaalde wetenschappelijke oplossing in een beleidsmaatregel te laten omzetten. Mag dat zomaar in een democratisch rechtsstaat?

Zolang wetenschap en politiek het met elkaar eens zijn, is van conflict geen sprake. Het primaat van de politiek wordt dan niet geschonden. Dat was overwegend het geval tijdens de eerste golf van de pandemie. Er trad zelfs een symbiose op tussen beide groepen: wetenschappers werden de facto beleidsmakers die door hun onpartijdigheid en deskundigheid veel vertrouwen genoten. Politici, overweldigd door de pandemie die zij initieel als volslagen leken beleefden, zochten houvast in de wetenschappen. Onderzoek van SCIENSANO toont aan dat de bevolking voornamelijk veel vertrouwen heeft in de gezondheidsdiensten en de wetenschappelijke instellingen en minder in de nationale, regionale en lokale overheden. ${ }^{12}$ Wetenschappers waren dus beter geplaatst om moeilijk verkoopbare maatregelen uit te leggen. Hun expertise werd geïnstitutionaliseerd in adviesorganen en crisiscellen, die aanvankelijk op harmonische wijze functioneerden. Politiek en media focusten op de wetenschap en experten waaronder virologen, epidemiologen en gezondheidsdeskundigen.

Toch was het niet altijd eenvoudig. In april en mei piekten de Belgische 'coronacijfers' in internationale rankings. ${ }^{13}$ Politici veroordeelden de rapportering op basis van een erg brede gevalsdefinitie, omdat die het imago van het land zouden schaden en een directe nefaste invloed op toerisme en handel zouden hebben. ${ }^{14}$ Wetenschappers gingen in het verweer met argumenten die zachtjesaan vergleden naar normatieve stellingnames: overschatting is verkiesbaar boven onderschatting, en negatieve neveneffecten op bijvoorbeeld de economie wegen minder zwaar dan de directe gezondheidswinst. Dergelijk indirect normatief optreden van wetenschappers was evenwel nog enigszins aanvaardbaar, omdat het afgeleide beleid nog voldoende politiek draagvlak kende.

Direct normstellend handelen van wetenschappers werd echter minder getolereerd naarmate de publieke steun voor de overheidsmaatregelen slonk en de kri-

14 www.vrt.be/vrtnws/nl/2020/04/22/belgische-corona-aanpak-door-de-ogen-van-deinternationale-pers. 
tiek toenam: te streng, te complex, niet logisch, tegenstrijdig, niet naleefbaar, economisch desastreus, asociaal, te streng gehandhaafd, ... Vooral in de virusluwe zomerperiode groeide het wederzijdse ongenoegen. Burgers begonnen te twijfelen aan het nut van de maatregelen en politici voelden de druk van belangengroepen, zoals de sportwereld, horeca en het bedrijfsleven. Het partnerschap tussen wetenschap en politiek begon barsten te vertonen. De strenge lijn van virologen en epidemiologen - en bij uitbreiding de meeste wetenschappers - begon af te wijken van de politieke koers. Academici die een wetenschappelijke rol met een politieke rol (in een adviesorgaan) combineerden, spraken openlijk over wat sociologen interne rolconflicten noemen. Dat viel niet altijd in goede aarde bij politici die dissenting opinions als een gebrek aan loyauteit labelden.

De spanning tussen wetenschappelijke en politieke rationaliteit werd op de spits gedreven bij de start van het nieuwe academiejaar aan de Belgische universiteiten eind september. Omdat beleidsmakers volgens de huisviroloog van de Universiteit Antwerpen onvoldoende rekening hielden met de objectieve feiten, passeerde de rector van de Universiteit Antwerpen boudweg de politieke instituties. Zijn boodschap aan de studenten liet niets aan de verbeelding over ${ }^{15}$ :

'Beste studenten, [...] We maken ons ten zeerste zorgen over de verspreiding van het Covid-19 virus in jullie groep. Op dit ogenblik heeft de Veiligheidsraad geopteerd voor nieuwe regels die, wat de studenten betreft hierop neerkomen: [...] $2^{\circ}$ voortaan mogen jullie ook, bijvoorbeeld aan de universiteit, een groep van maximaal vijf vormen, telkens voor een maand; dus met medestudenten bij wie je zonder mondmasker en met minder dan $1,5 \mathrm{~m}$ afstand $k a n$ vertoeven. Ons advies is om nu niet in te gaan op het aanbod van de Veiligheidsraad om op deze wijze zo'n nauwe contacten met elkaar aan te knopen.' (oorspronkelijke cursivering)

Tentatief kan gesteld worden dat de externe dimensie van verantwoordelijkheid van de wetenschapper zich vooral richt op de samenleving en het politieke bedrijf in instrumentele termen bekijkt. Politiek wordt gezien als een handige go-between of zelfs een noodzakelijk kwaad om bij te dragen aan de oplossing van maatschappelijke problemen. De overgrote meerderheid van wetenschappers houdt zich aan het voorschrift dat normatieve keuzes worden overgelaten aan de politieke klasse. Hun rol bestaat hoofdzakelijk in het bestuderen van problemen en het ontwikkelen van oplossingen die de basis vormen voor een evidence based-beleid. Slechts een handvol wetenschappers, die niet toevallig ook vaak leidende functies vervullen, legt het primaat van de politiek naast zich neer.

\section{Vier bijdragen}

Dit themanummer bundelt vier bijdragen die geïnspireerd zijn door 'corona en recht'. Drie van de vier teksten zijn gewijd aan de effecten van de Nederlandse 
maatregelen om de verspreiding van het nieuwe coronavirus in te dammen. Het vierde artikel start bij COVID-19. Ik duid elk artikel bondig in het raamwerk van de verantwoordelijkheid van de wetenschapper. Aspecten van de interne dimensie betreffen vooral de plaats die het artikel inneemt in de traditie van het sociaalwetenschappelijk onderzoek van het recht waarover Recht der Werkelijkheid intussen zo'n veertig jaar rapporteert. Kenmerken van de externe dimensie liggen hoofdzakelijk in de finaliteit die de auteurs aan hun onderzoek toekennen.

In 'Coronacrisis en rechtspleging' rapporteren Frans van Dijk en Eddy Bauw over een empirische verkenning van de impact van de coronacrisis op de rechtspleging. De benadering is deels beleidsmatig en deels constitutioneelrechtelijk (bijv. bescherming van de rechten van de partijen en bewaken van de rol van de rechter in de trias politica). Uiteindelijk zoeken de auteurs naar antwoorden op de voornaamste uitdagingen die de coronacrisis stelt voor het beleid en de rechtsstaat. Een overkoepelend antwoord zien de auteurs in de snelle ontwikkeling van ITtools, met het oog op verhoogde efficiëntie en daadwerkelijke rechtsbescherming in de rechtspleging aan de Nederlandse rechtbanken en hoven. De externe dimensie van de wetenschappelijke verantwoordelijkheid springt in het oog, niet enkel door de gerichte beleidsgeoriënteerde dataverzameling, maar vooral door de krachtige formulering van de urgentie van specifieke beleidsmaatregelen.

Ook in het volgende artikel richten de auteurs zich op de impact van de overheidsmaatregelen, en meer bepaald op de onbedoelde positieve effecten die de intelligente lockdown voortbracht. Edwin Kruisbergen, Marco Haas, Joanieke Snijders en Ron Maas bestudeerden de evolutie van verschillende types van criminaliteit tijdens de verplichte semiquarantaine. Het onderzoeksdoel was de vergelijkende toetsing van enkele criminologische theorieën. De steile toename van online criminaliteit en de parallelle daling van vermogenscriminaliteit leveren bewijs voor de opportuniteitstheorie. Het algemene peil van misdadige activiteit lijkt zich na een tijdelijke daling te stabiliseren rond een pre-coronaniveau. Een opvallende bevinding is dat goed onderbouwde predicties over toenames van geweld in de private sfeer - huiselijk geweld, relationele agressie - zich niet manifesteren in de politiecijfers. Of dit getuigt van een uitsteleffect is een belangrijke vraag. In het onderzoek wordt aan beide dimensies van wetenschappelijke verantwoordelijkheid recht gedaan. Het onderzoek draagt bij tot de theoretische ontwikkeling van de criminologie en reikt theoretisch onderbouwde empirische data aan die het strafrechtelijk beleid kunnen onderbouwen.

In het derde artikel, “Dividing the goods or dividing the beds?” De dreiging van triage in de risicomaatschappij', grijpt Tobias Arnoldussen de gelegenheid om de theorie van reflexieve modernisering van Ulrich Beck empirisch te toetsen. De kans is immers reëel dat de schaarste aan ic-bedden voor COVID-19-patiënten beleidsmakers zal confronteren met concrete verdelingsvraagstukken. Wie krijgt een bed, en wie niet? Via een kwalitatieve inhoudsanalyse van Nederlandse expertrichtlijnen en krantenartikelen wordt een beeld gevormd van de aard van het proces van reflexiviteit dat plaatsvindt in de discussie rond triage en de regulering ervan. Dat is op zichzelf genomen interessant, want Beck ziet dergelijke reflexieve processen als noodzakelijk om te komen tot nieuwe vormen van solidariteit binnen onze huidige 'risicomaatschappij'. De voornaamste doelstelling van dit artikel 
is echter een andere: kan het analysekader van reflexieve modernisering wellicht dienen om de maatschappelijke en juridische omgang met de coronacrisis als geheel te onderzoeken? De auteur positioneert zich vooral manifest sterk op de dimensie van de interne verantwoordelijkheid via het toetsen van de hypothese van de reflexieve modernisering. Toch impliceert dit niet dat de externe verantwoordelijkheid niet wordt ingevuld; uiteindelijk streeft de auteur naar de ontwikkeling van een analysekader voor de wijze waarop samenleving en recht met de coronacrisis omgaan. Zo'n kader kan op termijn nuttig zijn voor de evaluatie van het beleid.

De laatste bijdrage, 'Coronapandemie 2020: een kritisch perspectief', is een discussie van de hand van Roel Pieterman. In zijn betoog neemt de auteur een kritische houding aan tegenover het vigerende overheidsbeleid, en dan vooral de meest dramatische maatregel daarin: de lockdown, of 'een land op slot doen'. Hij durft luidop de vraag te stellen of het middel niet erger is dan de kwaal. Zijn standpunt is dat de politiek kansen op een realistischer onderbouwd beleid mist, doordat geen gebruik gemaakt wordt van de inzichten die een kosten-batenanalyse kan opleveren. Dat standpunt illustreert hij uitvoerig met gezondheidseconomische cijfers. Het stuk vindt inspiratie in interne en vooral externe verantwoordelijkheid: de auteur situeert de (afwezigheid van) kosten-batenanalyse bondig in het vakgebied, maar vooral in het politieke debat.

\section{Referenties}

Griffiths, J., 'The Social Working of Legal Rules', The Journal of Legal Pluralism and Unofficial Law, 2003-35, p. 1-84.

Munster, V.J., M. Koopmans, N. van Doremalen, D. van Riel \& E. de Wit, 'A novel coronavirus emerging in China - key questions for impact assessment', New England Journal of Medicine, 2020-382(8), p. 692-694.

Onder, G., G. Rezza \& S. Brusaferro, 'Case-Fatality Rate and Characteristics of Patients Dying in Relation to COVID-19 in Italy', JAMA (published online March 23, 2020), doi: 10.1001/jama.2020.4683.

Ritchie, H. \& M. Roser, What do we know about the risk of dying from COVID-19?, 2020, online: ourworldindata.org/covid-mortality-risk (geraadpleegd 17 oktober 2020).

Venkatesh, S. \& Z.A. Memish, 'SARS: the new challenge to international health and travel medicine', EMHJ - Eastern Mediterranean Health Journal 2004-10(4-5), p. 655-662.

Weber, M., 'Science as a Vocation', in: H.H. Gerth \& C. Wright Mills (eds.), From Max Weber: Essays in Sociology. New York: Oxford University Press 1946, p. 129-156, online: anthropos-lab.net/wp/wp-content/uploads/2011/12/Weber-Science-as-aVocation.pdf. Oorspronkelijk Max Weber, Wissenschaft als Beruf. Gesammlte Aufsaetze zur Wissenschaftslehre, Tubingen 1922, p. 524-555.

Weisz, E., 'Science, Rationalization, and the Persistence of Enchantment', Max Weber Studies 2020-20(1), p. 8-24. Online: jstor.org/stable/10.15543/maxweberstudies. 20.1.8. 